\title{
Serum total renin, an independent marker of the activity and severity of retinopathy in patients with IDDM
}

\author{
Sari Mäkimattila, Paula Summanen, Irma Matinlauri, Matti Mäntysaari, Anna Schlenzka, \\ Maija Aalto, Kerttu Irjala, Hannele Yki-Järvinen
}

Department of

Medicine, Division of

Endocrinology and

Diabetology, Helsinki

University Central

Hospital, Helsinki,

Finland

S Mäkimattila

A Schlenzka

H Yki-Järvinen

Department of Ophthalmology,

Helsinki University

Central Hospital,

Helsinki, Finland

P Summanen

Department of Clinical Chemistry, Turku

University Central

Hospital, Turku,

Finland

I Matinlauri

M Aalto

K Irjala

Research Institute of Military Medicine,

Central Military

Hospital, Helsinki,

Finland

M Mäntysaari

Correspondence to:

Hannele Yki-Järvinen, MD,

University of Helsinki,

Department of Medicine,

Division of Endocrinology

and Diabetology,

Haartmaninkatu 4,

FIN-00290 Helsinki,

Finland.

Accepted for publication

17 February 1998
Abstract

Backgroundlaims-Recent studies have demonstrated marked renin and prorenin concentration gradients between ocular tissues and blood, and local expression of the renin-angiotensin system (RAS) in the eye. The authors determined whether serum total renin, which mostly consists of prorenin, is a marker of the activity and severity of diabetic retinopathy independent of other microvascular complications. Methods-Total renin concentrations (TRC) were measured with a time resolved immunofluorometric assay in 38 patients with IDDM (age 34 (SD 7) years, duration of disease 22 (7) years, serum creatinine 95 (15) $\mu \mathrm{mol} / 1$, urinary albumin excretion rate (UAER) $207 \quad$ (829) $\mu \mathrm{g} / \mathrm{min}, \mathbf{H b A}_{1 c} \quad 8.5 \%$ $(1.2 \%))$, and in 13 matched normal subjects. All subjects were carefully characterised with respect to the presence and severity of retinopathy (RP score), nephropathy, and neuropathy using seven different tests of autonomic neuropathy.

Results-Serum TRC was on average twofold higher in IDDM (396 (SE 211) ng/l) than in normal subjects (201 (88) ng/l, $\mathbf{p}<0.001)$. It was nearly twofold higher in patients with preproliferative or active proliferative retinopathy requiring careful follow up or therapy (TRC 596 (268) ng/l, $n=11)$ compared with those with quiescent proliferative retinopathy after laser treatment (TRC 338 (183) ng/1, p<0.01, n=5); moderately severe non-proliferative retinopathy (337 (106) ng/l, p<0.01, n=13), no retinopathy, or only minimal nonproliferative retinopathy (270 (43) ng/l, $\mathbf{p}<0.001, \mathrm{n}=9)$. In multiple linear regression analysis, $R P$ score $(p<0.01)$, but not the UAER or any index of autonomic neuropathy, was an independent determinant of serum TRC, and explained $32 \%$ of its variation $(R=0.57$, $\mathrm{p}<0.005$ ).

Conclusions-Serum TRC in patients with diabetic retinopathy is increased independent of renal function and autonomic neuropathy, especially in those with severe active changes requiring careful follow up or treatment. These findings support the idea that diabetic retinopathy is the most important determinant of serum TRC in patients with IDDM, and that TRC is produced when retinopathy is active.

(Br F Ophthalmol 1998;82:939-944)

The aspartyl protease renin is the rate liming enzyme in the formation of the vasoactive octapeptide angiotensin II. ${ }^{1}$ In human blood prorenin, the precursor of renin, constitutes up to $90 \%$ of total renin. ${ }^{2}$ Classically, renin is considered to be a blood borne enzyme, which is synthesised and secreted from the juxtaglomerular apparatus. However, plasma prorenin is found in nephrectomised subjects in quantities close to those observed in normal individuals. ${ }^{34}$ These data suggest that, while circulating renin originates from the kidney, a large proportion of prorenin is produced at extrarenal sites such as adrenals, ${ }^{5}$ pituitary, ${ }^{5}$ testis, ${ }^{5}$ brain, ${ }^{6}$ and ovary, ${ }^{7}$ as well as some renal and extrarenal tumours. ${ }^{89}$

A marked concentration gradient in prorenin concentrations exists between bovine ocular tissues and blood. ${ }^{10}$ This gradient appears to be due to local production of prorenin, which is abundantly expressed in highly vascularised ocular parts such as the retina and choroid. ${ }^{11}$ In diabetic patients with proliferative retinopathy, prorenin concentrations in vitreous fluid are 100 times the level expected on the basis of the plasma protein content of ocular fluid. ${ }^{12}$ Prorenin concentrations in plasma are also elevated in patients with IDDM and proliferative retinopathy, independent of albuminuria. ${ }^{13}$ Thus, the eye could be the major source of elevated prorenin concentrations in IDDM. It is, however, unknown, whether the activity of retinopathy influences prorenin concentrations. In previous studies the classification of retinopathy has only been based on grading of retinopathy to proliferative, background, or no retinopathy.

In the present study we determined whether the serum total renin concentration (TRC) was influenced by severity and activity of diabetic retinopathy itself. Only males were included in 
Table 1 Characteristics of the study groups

\begin{tabular}{|c|c|c|c|}
\hline \multirow[b]{2}{*}{ Age (years) } & Normal subjects $(n=13)$ & \multicolumn{2}{|c|}{ IDDM patients $(n=38)$} \\
\hline & $34 \quad(8)$ & 34 & (7) \\
\hline Duration of diabetes (years) & - & 22 & (7) \\
\hline Body mass index $\left(\mathrm{kg} / \mathrm{m}^{2}\right)$ & $25.3(3.2)$ & 24.7 & $(2.4)$ \\
\hline Body fat (\%) & $17 \quad(5)$ & 17 & (5) \\
\hline $\mathrm{HbA}_{\mathrm{c}}(\%)$ & $5.2(0.5)$ & 8.5 & $(1.2)^{\star \star \star}$ \\
\hline Serum triglycerides $(\mathrm{mmol} / \mathrm{l})$ & $1.1(0.4)$ & 1.0 & $(0.3)$ \\
\hline Serum cholesterol $(\mathrm{mmol} / \mathrm{l})$ & $4.8(0.6)$ & 4.5 & $(0.9)$ \\
\hline Urinary albumin excretion $(\mu \mathrm{g} / \mathrm{min})$ & $9 \quad(4)$ & 207 & $(829)^{\star \star \star}$ \\
\hline Serum creatinine $(\mathrm{mmol} / \mathrm{l})$ & $93(10)$ & 95 & (15) \\
\hline Blood haemoglobin $(\mathrm{g} / \mathrm{l})$ & $147 \quad(6)$ & 151 & $(11)$ \\
\hline Blood pressure, systolic $(\mathrm{mm} \mathrm{Hg})$ & $126 \quad 18)$ & 126 & (14) \\
\hline Blood pressure, diastolic (mm Hg) & 72 (15) & 76 & $(8)$ \\
\hline Insulin dose (IU/ffm/d) & - & 0.84 & $(0.24)$ \\
\hline
\end{tabular}

$\star \star \star \mathrm{p}<0.001$ for IDDM patients $v$ control subjects. Data are expressed as mean and standard deviation of the mean (SD). the study since the menstrual cycle is known to influence TRC. ${ }^{78}$ The severity and activity of retinopathy was graded according to the classification developed for the EURODIAB IDDM Complications Study. ${ }^{14}$ The presence of nephropathy was determined from the urinary albumin excretion rate and neuropathy by performing seven different tests of autonomic nervous function.

\section{Methods}

SUBJECTS AND STUDY DESIGN

Thirty eight men with insulin dependent diabetes mellitus (IDDM) and 13 normal men volunteered for the studies. The diabetic patients were recruited from the outpatient clinic based on the following criteria: (1) age 18-50 years, (2) age at diagnosis of diabetes $<30$ years, (3) an undetectable fasting C peptide concentration $(<0.2 \mathrm{nmol} / \mathrm{l})$. The diabetic patients and the normal subjects were matched for age, body mass index (BMI), and body composition (Table 1).

A history, physical examination, and laboratory tests were performed on all subjects to exclude diseases other than diabetes mellitus. All patients and normal subjects had normal blood counts, electrolyte concentrations, and electrocardiograms (data not shown). The diabetic patients were treated with two $(n=6)$, three $(n=5)$, four $(n=22)$, five $(n=1)$, or six $(n=1)$ injections of a combination of intermediate and short acting insulins. Four patients were using continuous subcutaneous insulin infusion therapy. The mean insulin doses are shown in Table 1 . The patients did not take any other medication than insulin. The experimental protocol adhered to the principles of the Declaration of Helsinki, and was approved by the ethics committee of the Helsinki University Central Hospital. Informed written consent was obtained.

In each patient, the presence of microvascular complications was assessed as described below. A blood sample for measurement of serum TRC was taken at the time of fundus photography. The subjects were allowed to rest in supine position before the blood sample was drawn, and the serum for measurement of TRC was subsequently stored at $-20^{\circ} \mathrm{C}$. Three timed overnight urine collections for measurement of the urinary albumin excretion rate (UAER) were performed immediately before retinal photography. The autonomic
Table 2 Retinopathy severity grading scale ${ }^{14}$

\begin{tabular}{|c|c|}
\hline Level & Definition \\
\hline Level 10 & $\begin{array}{l}\text { No retinopathy/MA and all other lesions } \\
\text { absent. }\end{array}$ \\
\hline Level 20 & $\begin{array}{l}\text { Minimal/mild non-proliferative } \\
\text { retinopathy: } \\
\text { MAs only, or small retinal dot } \\
\text { haemorrhages indistinguishable from MAs } \\
\text { only; H/MA < SP1; with or without lipid } \\
\text { exudates. }\end{array}$ \\
\hline Level 30 & $\begin{array}{l}\text { Moderate non-proliferative retinopathy: } \\
\text { H/MAs } \geqslant S P 2 A \text { in only one field; or } \\
\text { H/MAs }<\text { SP } 2 A \text { with IRMA, and/or RMI } \\
\text { both }<\text { SP } 8 \text { A } \text { VB } \leqslant \text { SP } 6 \text { A, or }>\text { SP } 6 \text { A in } \\
\text { only one vein. }\end{array}$ \\
\hline Level 40 & $\begin{array}{l}\text { Severe non-proliferative retinopathy: } \\
\mathrm{H} / \mathrm{MAs} \geqslant \mathrm{SP} 2 \mathrm{~A} \text { in both fields, or if only } \\
\text { in one field with IRMA or RMI both } \geqslant S P \\
8 \mathrm{~A} \text {; or } \mathrm{VB}>\mathrm{SP} 6 \mathrm{~A} \text { in two veins or more. }\end{array}$ \\
\hline Level 50 & $\begin{array}{l}\text { Inactive/quiescent proliferative } \\
\text { retinopathy: } \\
\text { No evidence of active new vessels cut } \\
\text { some retinopathy changes of level } 20-30 \\
\text { changes possible as well as fibrous } \\
\text { proliferation with photocoagulation scars } \\
\text { either in scatter or confluent patches } \\
\text { (panretinal photocoagulation). }\end{array}$ \\
\hline Level 60 & $\begin{array}{l}\text { Active proliferative retinopathy: } \\
\text { New vessels on the disc and/or the retina } \\
\text { with or without scars of photocoagulation. }\end{array}$ \\
\hline
\end{tabular}

function tests were performed on a separate occasion within a month from fundus photography and the UAER measurements.

\section{RETINAL PHOTOGRAPHS}

The presence and severity and activity of diabetic retinopathy was assessed using two $45^{\circ}$ fundus colour slides representing macular and disc/nasal field ${ }^{14}$ taken from each eye through dilated pupils. Photographs were graded in a masked fashion by an ophthalmologist (PS) based on the classification developed for the EURODIAB IDDM Complications Study. ${ }^{14}$ For each eye, the maximum grade of the diabetic lesions, microaneurysms, haemorrhages, lipid exudates, intraretinal microvascular abnormalities, retinal microinfarctions, venous beading, new vessels, vitreous and preretinal haemorrhages, was determined to produce an overall severity level for an eye (RP score) (Table 2). The score of the more severely affected eye was used to represent a patient. All patients who were found to have active neovascularisation in spite of previous laser treatment were re-examined and given further laser therapy (PS). Active new neovascularisation was judged from the presence of curly neovascular vessels along the retinal surface. These vessels were often adjacent to previous laser scars. In contrast with this, in inactive proliferative retinopathy only dense laser scars with or without fibrous proliferations and no open vessels were seen.

ASSESSMENT OF AUTONOMIC FUNCTION

The subjects underwent the autonomic cardiovascular nervous function tests ${ }^{15}$ between $2 \mathrm{pm}$ and $4 \mathrm{pm}$ while on their regular medication. Except for the orthostatic test, the tests were performed in the supine position. The tests were performed in the following order: the controlled and deep breathing tests, the 
Table 3 Characteristics of the IDDM patients grouped by the severity of the diabetic retinopathy

\begin{tabular}{|c|c|c|c|c|c|}
\hline & Normal subjects & $\begin{array}{l}\text { IDDM none to minimal } \\
\text { non-proliferative } \\
\text { retinopathy } \\
(R P \text { score } 10,20)\end{array}$ & $\begin{array}{l}\text { IDDM moderate } \\
\text { non-proliferative } \\
\text { retinopathy } \\
(R P \text { score } 30)\end{array}$ & $\begin{array}{l}\text { IDDM quiescent } \\
\text { proliferative } \\
\text { retinopathy } \\
(R P \text { score 50) }\end{array}$ & $\begin{array}{l}\text { IDDM severe non-proliferative } \\
\text { or active proliferative } \\
\text { retinopathy } \\
(R P \text { score } 40,60)\end{array}$ \\
\hline Subjects & 13 & 9 & 13 & 5 & 11 \\
\hline Age (years) & $34(8)$ & $29(6)^{\star}$ & $35(7)$ & $36(7)$ & $36(7)$ \\
\hline Duration of diabetes (years) & - & $18(6) \dagger$ & $21(8)$ & $25(5)$ & $25(4)$ \\
\hline Body mass index $\left(\mathrm{kg} / \mathrm{m}^{2}\right)$ & $25.3(3.2)$ & $24.5(1.6)$ & $24.2(3.1)$ & $24.4(2.5)$ & $25.5(2.0)$ \\
\hline Body fat $(\%)$ & $17(5)$ & $17(5)$ & $19(6)$ & $16(4)$ & $16(4)$ \\
\hline $\mathrm{HbA}_{1 \mathrm{c}}(\%)$ & $5.2(0.5)^{\star \star \star}$ & $7.8(0.8)^{\star \star}, \dagger$ & $8.8(1.4)$ & $7.8(0.8)$ & $9.2(1.0)$ \\
\hline Urinary albumin excretion $(\mu \mathrm{g} / \mathrm{min})$ & $9(4)$ & $7(3)$ & $10(9)$ & $208(349)+\dagger$ & $602(1495)+\dagger$ \\
\hline Blood pressure, systolic (mmHg) & $126(18)$ & $120(11)$ & $122(11)$ & $128(7)$ & $133(19)$ \\
\hline Blood pressure, diastolic $(\mathrm{mmHg})$ & $72(15)$ & $73(9)$ & $74(4)$ & $78(7)$ & $79(10)$ \\
\hline Insulin dose $(\mathrm{IU} / \mathrm{ffm} / \mathrm{d})$ & - & $0.75(0.28)$ & $0.94(0.27)$ & $0.80(0.20)$ & $0.81(0.16)$ \\
\hline Serum total renin $(\mathrm{ng} / \mathrm{l})$ & $201(88) \neq \neq \ddagger$ $\subseteq$ & $270(43)$ & $337(106)$ & $338(183)$ & $596(268)+十 \dagger$, 㧊 \\
\hline
\end{tabular}

$\star_{\star \star \star} \mathrm{p}<0.001$ for normal subjects $v$ IDDM patients; ${ }^{\star \star} \mathrm{p}<0.01$ for IDDM patients with RP score 10 or $20 v$ patients with RP score 40 or $60,{ }^{\star} \mathrm{p}<0.05$ for IDDM patients with RP score 10 or $20 v$ patients with RP score 40 or 60 . $\dagger \dagger \dagger p<0.001$ for IDDM patients with RP score 40 or $60 v$ patients with RP score 10 or 20 and normal subjects, $t+p<0.01$ for IDDM patients with RP score 50,40 or $60 v$ other IDDM patients, $t p<0.05$ for IDDM patients with RP score 10 or $20 v$ patients with RP score 50 . $\neq \neq \ddagger \mathrm{p}<0.001$ for normal subjects $v$ IDDM patients with RP core 30,40 , or $60, \ddagger \neq \mathrm{p}<0.01$ for IDDM patients with RP score 40 or $60 v$ patients with RP score 30 or 50 . $\ddagger \mathrm{p}<0.05$ for IDDM patients with RP score 10 or $20 v$ patients with RP score $30 . \$ \mathrm{p}<0.05$ for normal subjects $v$ IDDM patients with RP score 10 or 50 . Data are expressed as mean and standard deviation of the mean (SD).

Valsalva test, and the orthostatic test. In the controlled breathing test, a measure of both parasympathetic and sympathetic inputs into heart rate control,,$^{15}$ a quiet sound signal was given to pace the inspiration and expiration for 2 seconds each. This pattern was maintained for 5 minutes, during which the R-R intervals were measured from the electrocardiogram. The square root of the mean of the square of successive R-R interval differences (RMSSD) was calculated. The frequency domain analysis of heart rate variability was done using spectral analysis of $\mathrm{R}-\mathrm{R}$ interval variability using the CAFTS system (Medicro Oy, Kuopio, Finland). After detrending the R-R interval signal, a least mean square autoregressive model with a model order of 14 was used to obtain the power spectral estimate of R-R interval variability. The total power (TP) was determined in the frequency range from 0 to 0.5 times heart rate in $\mathrm{Hz}$. Low frequency power (LF) was determined in the frequency range from 0.04 to $0.15 \mathrm{~Hz}$, and it is thought to be mediated by both parasympathetic and sympathetic pathways. ${ }^{16} 17$ High frequency power $(\mathrm{HF})$ was determined in the frequency rage from 0.15 to $0.40 \mathrm{~Hz}$, and it is thought to be mediated by parasympathetic pathways. ${ }^{16} 17$ The signal powers were calculated as integrals under the respective part of the power spectral density function, and were expressed in absolute units $\left(\mathrm{ms}^{2}\right)$, and in relation $(\mathrm{LF} / \mathrm{HF})$ as a measure of "sympathovagal balance". ${ }^{18} 19$ In the deep breathing test, a test of vagal heart rate control, ${ }^{15}$ the duration of inspiration and expiration was 5 seconds for both for 40 seconds (four respiratory cycles). The ratio of the longest and shortest R-R intervals was determined from the electrocardiogram for each respiratory cycle, and the mean of the four ratios was taken as the expiration to inspiration ratio (E/I ratio). In the Valsalva test, a measure of both parasympathetic and sympathetic function, ${ }^{15}$ the subjects blew into a manometer thereby maintaining an intrathoracic pressure of 40 $\mathrm{mm} \mathrm{Hg}$ for 15 seconds. The ratio of the shortest R-R interval during the expiratory strain and the longest R-R interval during the $20 \mathrm{sec}$ onds after the end of the strain was calculated (Valsalva ratio). In the orthostatic test the subjects stood up after resting quietly supine for 5 minutes. Heart rate and blood pressure were measured at rest and 1, 3, 5, and 7 minutes after standing up.

\section{STAGING OF DIABETIC NEPHROPATHY}

Three timed overnight urine collections were obtained in the diabetic patients and once in the normal subjects to classify the subjects according to their UAER (Table 1). Normoalbuminuria was defined as an UAER below $20 \mu \mathrm{g} / \mathrm{min}$, microalbuminuria between 20 and $200 \mu \mathrm{g} / \mathrm{min}$, and macroalbuminuria as a rate over $200 \mu \mathrm{g} / \mathrm{min}$ in at least two out of the three consecutive overnight urine samples. ${ }^{20}$

\section{SERUM TOTAL RENIN CONCENTRATION}

The TRC in serum was measured with a modification of a time resolved immunofluorometric assay. ${ }^{21}$ The method was based on a sandwich type immunoassay with two monoclonal anti-human renin antibodies (clones R3-27-6 and R3-36-16, Ciba-Geigy, Basel, Switzerland). Preparation of renin (code 68/ 356; National Institute for Biological Standards and Control, Herts) was used to calibrate the renin standards. Within assay precision (CV) was $2.1 \%$ at the renin concentration of $100 \mathrm{ng} / \mathrm{l} \quad(\mathrm{n}=12)$, and $1.4 \%$ at the renin concentration of $750 \mathrm{ng} / \mathrm{l} \quad(\mathrm{n}=12)$. Between assay precision was $5.0 \%$ at the renin concentration of $130 \mathrm{ng} / \mathrm{l}(\mathrm{n}=6)$, and $3.2 \%$ at the renin concentration of $1320 \mathrm{ng} / \mathrm{l}(\mathrm{n}=6)$. All serum TRC measurements were performed at least 1 month after photocoagulation (mean 2 years, range 1 month -6 years, $n=10$ ).

\section{OTHER MEASUREMENTS}

Glycated haemoglobin $\left(\mathrm{HbA}_{1}\right)$ was measured by high performance liquid chromatography ${ }^{22}$ using the fully automated glycosylated haemoglobin analyser System (BioRad, Richmond, CA, USA). Urine albumin was measured by an immunoturbidimetric (Hitachi 911, Tokyo, Japan) method using an antiserum against human albumin (Orion Diagnostica, Espoo, Finland). Serum creatinine was determined by enzymatic kinetic analysis using Jaffe's reaction in a multichannel automatic analyser (Hitachi). Body composition was determined 


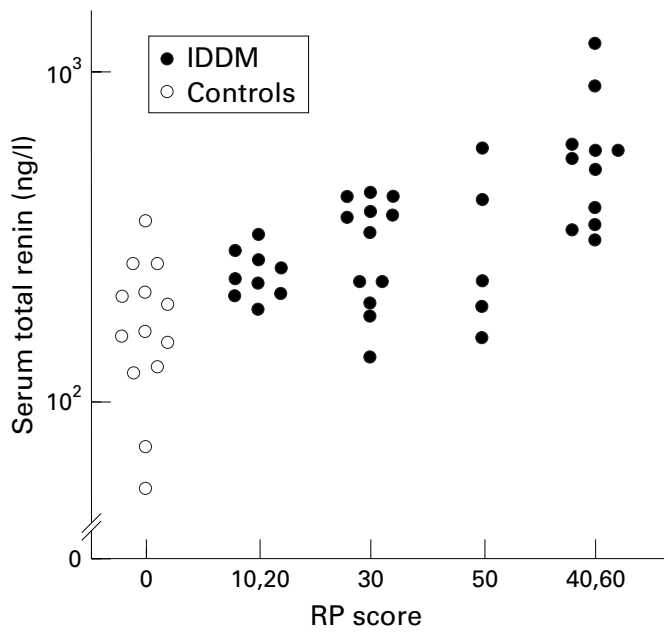

Figure 1 The relation between the retinopathy level and serum total renin (log) concentration.

by using bioelectrical impedance (BioElectrical Impedance Analyzer System, Model \#BIA-101A, Mf Clemens, MI, USA). ${ }^{23}$

\section{STATISTICAL METHODS}

Data between the two study groups were compared using the Student's $t$ test. Data between more than two groups were compared using analysis of variance (ANOVA) followed by pairwise comparison using Fisher's least significant difference test. Differences between urinary albumin excretion rates were compared using the Mann-Whitney rank sum test. Simple correlations between selected study variables were calculated using Spearman's rank correlation coefficient. Multiple linear regression analysis was used to analyse the causes of variation in variables of serum total renin, retinopathy level, UAER, and autonomic neuropathy. Total renin and UAER were log transformed to normalise their distribution for multiple linear regression analysis. All calculations were made using the SYSTAT statistical package (Systat Inc, Evanston, IL, USA). All data are expressed as means and standard deviation of mean (SD).

\section{Results}

DIABETIC RETINOPATHY AND SERUM TOTAL RENIN

To examine the effect of the severity and activity of the diabetic retinal vascular changes on serum TRC, the diabetic patients were divided into four groups according to the need of treat-

Table 4 Results of autonomic nervous system tests in the study groups

\begin{tabular}{|c|c|c|c|}
\hline Test & Variable & $\begin{array}{l}\text { Normal subjects } \\
(n=8)\end{array}$ & $\underset{(n=35)}{I D D M}$ patients \\
\hline Controlled breathing & RMSSD (ms) & $38.3(13.7)$ & $30.3(35.0)$ \\
\hline Controlled breathing & $\mathrm{TP}\left(\mathrm{ms}^{2}\right)$ & $2969(2438)$ & $1860(4397)$ \\
\hline Controlled breathing & $\mathrm{LF}\left(\mathrm{ms}^{2}\right)$ & $545(300)$ & $398(630)$ \\
\hline Controlled breathing & $\mathrm{HF}\left(\mathrm{ms}^{2}\right)$ & $618(366)$ & $427(488)$ \\
\hline Controlled breathing & $\mathrm{LF} / \mathrm{HF}$ ratio & $1.0(0.7)$ & $1.5(1.5)$ \\
\hline Deep breathing & $\mathrm{E} / \mathrm{I}$ ratio & $1.3(0.1)$ & $1.3(0.2)$ \\
\hline Valsalva manoeuvre & Valsalva ratio & $1.9(0.3)$ & $1.7(0.3)^{\star}$ \\
\hline Orthostatic test, 7 minutes & $\begin{array}{l}\text { Systolic blood pressure decrease } \\
(\mathrm{mm} \mathrm{Hg})\end{array}$ & $-2.9(10.0)$ & $-5.6(12.3)$ \\
\hline
\end{tabular}

${ }^{\star} \mathrm{p}<0.05$ for IDDM patients $v$ normal subjects. Data are expressed as mean (SD).

RMSSD = square root of the mean of the square of R-R interval differences.

$\mathrm{TP}=$ total power.

$\mathrm{LF}=$ low frequency

$\mathrm{HF}=$ high frequency component of heart rate variability in spectral analysis. ment of diabetic retinopathy (Table 3). Serum TRC was significantly higher in all IDDM groups compared with the normal subjects (Table 3). Serum TRC was twofold higher in patients with preproliferative or active proliferative retinopathy requiring careful follow up or laser therapy (596 (SD 268) ng/l) compared with patients with previously laser treated quiescent proliferative retinopathy (338 (183) $\mathrm{ng} / \mathrm{l}, \mathrm{p}<0.01)$, those with moderately severe non-proliferative retinopathy (337 (106) ng/l, $\mathrm{p}<0.01$ ), or patients with no or only minimal non-proliferative retinopathy $(270$ (43) $\mathrm{ng} / \mathrm{l}$, $\mathrm{p}<0.001, \mathrm{n}=9$ ) (Fig 1).

INTERRELATION BETWEEN SERUM TOTAL RENIN, RETINOPATHY, AND OTHER MICROVASCULAR COMPLICATIONS

In simple regression analysis, RP score $(r=0.53, \mathrm{p}<0.001), \mathrm{HbA}_{1 \mathrm{c}}(r=0.40, \mathrm{p}<0.05)$, and duration of diabetes $(r=0.36, \mathrm{p}<0.05)$ were positively correlated with total renin. Serum TRC was not correlated with UAER, systolic or diastolic blood pressure, heart rate, or results of other autonomic function tests. In multiple linear regression analysis, RP score $(p<0.01)$, but not the UAER or any index of autonomic neuropathy, was an independent determinant of serum TRC, and explained $32 \%$ of its variation $(\mathrm{R}=0.57, \mathrm{p}<0.005)$.

\section{Discussion}

In the present study, compared with normal subjects, patients with IDDM as one group or divided in four groups according to severity and activity of retinopathy had significantly higher serum TRC. The increase in TRC was independent of other microvascular complications. Serum TRC were nearly twofold higher in patients with preproliferative or active proliferative retinopathy requiring careful follow up or therapy than in those with laser treated quiescent proliferative retinopathy. These data provide evidence for a relation between serum TRC and severity and activity of diabetic retinopathy. They extend the previous findings by demonstrating that even mild signs of diabetic retinopathy are associated with increased concentrations of prorenin, ${ }^{24}$ and that TRC are higher in active than inactive proliferative retinopathy. ${ }^{1325}$

In simple regression analysis, in addition to $\mathrm{RP}$ score, duration of diabetes and $\mathrm{HbA}_{1 \mathrm{c}}$ were positively correlated with TRC, supporting the previous observations of Luetcher et al ${ }^{26}$ and Franken et al. ${ }^{13}$ In our series, TRC was not correlated with systolic or diastolic blood pressure, consistent with findings with Franken et $a l,{ }^{13}$ nor with any index of autonomic neuropathy. The latter contrasts the finding of elevated prorenin concentrations in four non-diabetic patients with autonomic neuropathy, ${ }^{27}$ but agrees with the data of Franken et al, ${ }^{13}$ who found normal prorenin concentrations in 16 non-diabetic patients with advanced autonomic neuropathy. Furthermore, the lack of an arteriovenous concentration difference across the kidney in diabetic patients with high prorenin and end stage kidney disease ${ }^{13}$ is consistent with 
the idea that serum prorenin is of extrarenal origin in patients with IDDM. Franken et $a l^{1325}$ also showed, again in keeping with the present data, that retinopathy, particularly the proliferative type, was an independent determinant of abnormally high plasma prorenin, independent of the presence of neuropathy and nephropathy.

Prorenin in vitreous fluid from eyes of diabetic patients with traction retinal detachment is up to 100 -fold higher relative to albumin and other plasma proteins, and higher than in non-diabetic subjects with recurrent retinal detachment complicated by proliferative vitreoretinopathy. ${ }^{12}$ The highest renin and prorenin concentrations are found in the order: subretinal fluid $>$ vitreous $>$ aqueous humour. ${ }^{12}$ The exact location of prorenin production is unknown, although renin mRNA expression has recently been found using RNAse protection assay in pooled retinal pigment epithelium-choroid samples, but not in neural retina alone. ${ }^{11}$ Some renin mRNA has also been detected in the neural retina using the reverse transcription polymerase chain reaction (RT-PCR). ${ }^{11}$ Angiotensinogen and angiotensin converting enzyme gene expression was demonstrated by RT-PCR in individual retinal pigment epithelium-choroid and neural retina samples. ${ }^{11}$ Berka et al ${ }^{28}$ showed that renin is synthesised in the retina and specifically localised this to macroglial Müller cells. It is, however, unknown whether activated RAS in the eye is a cause or an effect of an eye disease. ${ }^{29}$ The end product of RAS, angiotensin II, is known to stimulate angiogenesis in a rabbit cornea ${ }^{30}$ and chorioallantoic membrane of the chick embryo. ${ }^{31}$ Furthermore, it is a potent vasoconstrictor also in the retina, ${ }^{32} 33$ and promotes hypertrophy and hyperplasia of vascular smooth muscle cells. ${ }^{34}{ }^{35}$ Vitreous levels of angiotensin II have also been found to be increased in patients with diabetic retinopathy. ${ }^{36}$ Thus, RAS is suspected to be involved in the regulation of blood flow and development of neovascularisation in the retina.

Franken et $a l^{1325}$ graded retinopathy into three groups (no, background or proliferative). We used a more detailed grading according to the EURODIAB IDDM method $^{14}$ based on the principles of the modified Airlie House classification. ${ }^{37}$ When grouping diabetic patients according to the need of further treatment, we combined patients with severe non-proliferative (preproliferative) retinopathy with those with active proliferative retinopathy, since angiogenesis is evolving already during the preproliferative stage. Franken $e t a l^{13}$ included these patients in the group of background retinopathy. Furthermore, they included patients in the group of proliferative retinopathy when one or both eyes had been laser treated, but the activity of retinopathy at the time of the study was not specified.

Our data provide evidence for a relation between TRC and severity and activity of diabetic retinopathy, and thus for the role of TRC in the pathogenesis of diabetic retinopathy.
Mean TRC was significantly higher in patients with severe non-proliferative or active proliferative retinopathy than in those with quiescent laser treated proliferative retinopathy. On the basis of our pilot study, it would be tempting to speculate that TRC could be helpful in identifying patients with persistent active proliferation or new neovascularisation years after panretinal photocoagulation.

Supported by grants from the Academy of Finland (HY), the Sigrid Juselius Foundation (HY) and the Finnish Diabetes Sigrid Juselius Foundation

We thank Ms Kati Tuomola and Ms Sari Hämäläinen for excellent technical assistance, Mr Ronald Klein, for valuable help in the planning of the grading of fundus photographs, Ms Soile Aarnio for drawing the figure and the volunteers for their help.

1 Hsueh WA, Anderson PW. Hypertension, the endothelia cell, and the vascular complications of diabetes mellitus. cell, and the vascular complica

2 Sealey JE, Atlas SA, Laragh JH. Prorenin and other large molecular weight forms of renin. Endocr Rev 1980;1:365 91

3 Sealey JE, Moon C, Laragh JH, et al. Plasma prorenin in normal, hypertensive and anephric subjects and its effect on renin measurements. Circ Res 1977;40 (Suppl 1):41-5.

4 Sealey JE, White P, Laragh JH, et al. Plasma prorenin and renin in anephric patients. Circ Res 1977;41 (Suppl 2):1721.

5 Naruse K, Murakoshi M, Osamura RY, et al. Immunohistological evidence for renin in human endocrine tissues. $\mathcal{F}$ Clin Endocrinol Metab 1985;61:172-7.

6 Ganten D, Printz M, Phillips MI, et al. The reninangiotensin system in the brain. Exp Brain Res 1982;48 (Suppl 4):5.

7 Glorioso N, Atlas SA, Laragh JH, et al. Prorenin in high concentrations in human ovarian follicular fluid. Science 1986;233:1422-4.

8 Ariza A, Fernandez LA, Inagami T, et al. Renin in glioblastoma multiforme and its role in neovascularization. $A m \mathcal{F}$ Clin Pathol 1988;90:437-41.

9 Corvol P, Pinet F, Galen FX, et al. Seven lessons from seven renin secreting tumors. Kidney Int 1988;34 (Suppl 25) S38-44.

10 Deinum J, Derkx FHM, Danser AHJ, et al. Identification and quantification of renin and prorenin in the bovine eye. Endocrinology 1990;126:1673-82.

11 Wagner J, Danser AHJ, Derkx FHM, et al. Demonstration of renin mRNA, angiotensinogen mRNA, and angiotensin of renin mRNA, angiotensinogen mRNA, and angiotensin
converting enzyme mRNA expression in the human converting enzyme mRNA expression in the human eye:evidence for an intraocular re
Br $\mathcal{7}$ Ophthalmol 1996;80:159-63.

12 Danser AHJ, van den Dorpel MA, Deinum J, et al. Renin, prorenin, and immunoreactive renin in vitreous fluid from eyes with and without diabetic retinopathy. $f$ Clin Endocrinol Metab 1989;68:160-7.

13 Franken AAM, Derkx FHM, Man in't Veld AJ, et al. High plasma prorenin in diabetes mellitus and its correlation with some complications. $f$ Clin Endocrinol Metab 1990;71: $1008-15$

14 Aldington SJ, Kohner EM, Meuer S, et al. Methodology for retinal photography and assessment of diabetic retinal photography and assessment of diabetic retinopathy: the EUabetologia 1995;38:437-44.

15 Ewing DJ. Analysis of heart rate variability and other non-invasive tests with special reference to diabetes mellitus. In: Bannister R, Mathias CJ, eds. Autonomi failure. A textbook of clinical disorders of the autonomic nervous system. 3rd ed. Oxford: Oxford University Press, 1992:31233.

16 Pomeranz B, Macaulay RJB, Caudill MA, et al. Assessment of autonomic function in humans by heart rate spectral analysis. Am f Physiol 1985;248:H151-3.

17 Akselrod S, Gordon D, Madwed JB, et al. Hemodynamic regulation: investigation by spectral analysis. Am $\mathcal{F}$ Physiol 1985;249:H867-75.

18 Pagani M, Lombardi F, Guzzetti S, et al. Power spectral analysis of heart rate and arterial pressure variabilities as a
marker of sympatho-vagal interaction in man and conmarker of sympatho-vagal interaction

19 Furlan R, Guzzetti S, Crivellaro W, et al. Continuou 24-hour assessment of the neural regulation of systemic arterial pressure and RR variabilities in ambulant subjects. Circulation 1990;81:537-47.

20 American Diabetes Association and the National Kidney Foundation. Consensus development conference on the diagnosis and management of nephropathy in patients with diabetes mellitus. Diabetes Care 1994;17:1357-61.

21 Matinlauri IH, Rönnemaa T, Koskinen P, et al. Elevated serum total renin is insensitive in detecting incipient diabetic nephropathy. Diabetes Care 1995;18:1357-61.

22 Cole RA, Soeldner JS, Dunn PJ, et al. A rapid method for the determination of glycosylated hemoglobins using high pressure liquid chromatography. Metabolism 1978;27:289301 
23 Rising R, Swinburn B, Larson K, Ravussin E. Body composition in Pima Indians: validation of bioelectrical resistance. Am f Clin Nutr 1991;53:594-8.

24 Wilson DM, Luetscher JA. Plasma prorenin activity and complications in children with insulin-dependent diabetes mellitus. N Engl f Med 1990;323:1101-6.

25 Franken AAM, Derkx FHM, Schalekamp MADH, et al. Association of high plasma prorenin with diabetic retinopathy. F Hypertens 1988;6 (Suppl 4):S461-3.

26 Luetscher JA, Kraemer FB, Wilson DM, et al. Increased plasma inactive renin in diabetes mellitus. A marker of microvascular complications. $N$ Engl f Med 1985;312 1412-7.

27 Misbin RI, Grant MB, Pecker MS, et al. Elevated levels of plasma prorenin (inactive renin) in diabetic and nondiabetic patients with autonomic dysfunction. F Clin Endocrinol Metab 1987;64:964-8.

28 Berka JL, Stubbs AJ, Wang DZ, et al. Renin-containing Müller cells of the retina display endocrine features. Invest Müller cells of the retina display end
Ophthalmol Vis Sci 1995;36:1450-8.

29 van Haeringen NJ. The renin-angiotensin system in the human eye. Br $\mathcal{F}$ Ophthalmol 1996;80:99-100.

30 Fernandez LA, Twickler J, Mead A. Neovascularization produced by angiotensin II. F Lab Clin Med 1985; 105:141-5.
31 Le Noble FAC, Hekking JWM, Van Straaten HWM, et al. Angiotensin II stimulates angiogenesis in the chorioallantoic membrane of the chick embryo. Eur $\mathcal{F}$ Pharmacol 1991;195:305-6.

32 Ferrari-Dileo G, Davis EB, Anderson DR. Angiotensin binding sites in bovine and human retinal blood vessels. Invest Ophthalmol Vis Sci 1987;28:1747-51.

33 Rockwood EJ, Fantes F, Davis EB, et al. The response of retinal vasculature to angiotensin. Invest Ophthalmol Vis $\mathrm{Sci}$ 1987;28:676-82.

34 Naftilan AJ, Pratt RE, Dzau VJ. Induction of plateletderived growth factor A-chain and c-myc gene expressions by angiotensin II in cultured rat vascular smooth muscle cells. $\mathcal{F}$ Clin Invest 1989;83:1419-24.

35 Itoh H, Pratt RE, Gibbons G, et al. Angiotensin II modulates proliferation of vascular smooth muscle cells (VSMS) via dual autocrine loops of TGF-beta and bFGF Hypertension 1991;18:396.

36 Goel AK, Jabbour NM. Vitreous levels of angiotensin II in patients with diabetic retinopathy. Invest Ophthalmol Vis Sci 1991;32:1027.

37 Early Treatment Diabetic Retinopathy Study Research Group. Grading diabetic retinopathy from steroscopic color fundus photographs - an extension of the modified Airlie House classification. ETDRS report number 10 Ophthalmology 1991;98:786-806. 